Ann. Génét. Sél. anim., I972, 4 (4), 495-503.

\title{
CHROMOSOMES OF CHICKEN-PHEASANT HYBRIDS
}

\author{
Parvathi K. BASRUR and S. YAMASHIRO \\ Department of Biomedical Sciences, \\ Ontario Veterinary College, \\ University of Guelph, \\ Guelph, Ontario, Canada
}

\begin{abstract}
SUMMARY
Chromosome analysis on 34 hybrid embryos obtained by two way crosses between Columbian Rock chickens (Gallus domesticus) and ring-necked pheasants (Phasianus colchicus) revealed that a majority of the embryos carry a haploid set each of chicken and pheasant chromosomes. Three of the male embryos resulting from chicken female-pheasant male crosses were cytogenetically indistinguishable from male domestic chicken whereas two embryos obtained from a similar cross, were chimeras composed of chicken cells and hybrid cells. The presence of hybrid embryos of chicken karyotype is attributable either to parthenogenesis in the hens or to fertilization of the hens ovum by rooster spermatozoa from previous matings, surviving in the female reproductive tract. It is postulated that the chimeric hybrids may be the result of double fertilization of the ovum and its retained polar body, and that the spermatozoa from the semen invested during this investigation and the rooster spermatozoa remaining viable in the hens oviduct from previous matings, were probably involved in this process.
\end{abstract}

Studies on intergeneric hybrids obtained by crossing ring-necked pheasant and Columbian Rock chickens have shown that only less than thirty percent of the eggs laid were fertile (BASRUR, I969; BHATNAGAR, I968). It was observed that among the fertile eggs incubated, over fifty percent died at various times before hatching (BASRUR, I 969). The exact reason for the high mortality rate in chickenpheasant hybrids is not known although it is generally noted that the hybrid progeny are at great developmental disadvantage if the two species involved in hybridization are dissimilar in their cytogenetic make up (BENIRschke, et al., I965). Higher fertility has been reported in matings of domestic chicken roosters to pheasant females than that noted in reciprocal crosses (ASMONDSON and LORENZ, I957) although hatchability was noted to be much lower in the chicken male-pheasant female crosses 
(BASRUR, I969). The present report concerns our preliminary observations during an investigation on the cytogenetic basis of embryonic mortality in chicken-pheasant hybrids.

\title{
MATERIALS AND METHODS
}

\begin{abstract}
Nineteen embryos belonging to ring necked pheasant female - chicken male crosses, and fifteen embryos resulting from domestic chicken female - ring-necked pheasant male crosses were used for karyotype analysis. The eggs were incubated for 16 to 20 days prior to removing the embryos for sexing and for tissue culture. The embryos were first decapitated and the anatomic sex of each embryo was recorded on the basis of the number of gonads : paired in males and single in females. For the histological confirmation of the sex, gonads were removed and fixed in ro p. I oo neutral buffered formalin and processed according to the routine haematoxylin and eosin $(\mathbf{H}$ and E) method.

The hind limbs of each embryo were removed asceptically and were freed from skin and bones before rinsing in sterile phosphate buffered saline (PBS). The tissue was chopped with a pair of sterile Bard-Parker knives and the pieces were triturated in $0.25 \mathrm{p}$. Ioo trypsin at room temperature on a Magnastir, for 15 minutes. The mince was passed through a glass funnel fitted with cheese cloth filter and the filterate was spun at 600 r.p.m. for 8 minutes. The centrifugation was repeated replacing the trypsin solution with PBS containing a drop of calf serum, and the cell button was suspended in growth medium $\mathrm{H} 597$ supplemented with 20 p. Ioo calf serum and antibiotics (BASRUR and GILMAN, I963). Leighton tubes, seeded with approximately 200 ooo cells per $\mathrm{ml}$ of growth medium were incubated at $37^{\circ} \mathrm{C}$.

The day-old cultures were replenished with fresh growth medium and on day two, the mitotic cells were accumulated by the exposure of cultures to colchicine at a final concentration of o.00I p. Ioo, for 4 hours prior to terminating the cultures. Aceto-orcein stained chromosome preparations were made according to the procedure described previously (BASRUR and GILMAN, 1966) and metaphase plates with well spread chromosomes were selected and photographed with phase optics on a Zeiss Photomicroscope. From each culture over 50 cells were examined and the cytogenetic make up of the embryos were recorded on the basis of their macrochromosomes including the sex complements.
\end{abstract}

\section{RESULTS AND DISCUSSION}

A majority of the embryos used in this study (25 out of 34 ) were males on the basis of gonadal histology although in three of these males a well developed gonad was detected only on the left side while the right gonad was vestigeal. Nine of the embryos were recorded as females on the basis of the histologic feature of their gonads.

Karyotype analysis confirmed the hybrid constitution of 29 embryos all of which carried a set each of chicken and pheasant chromosomes (Plate I). The histologic males (table I) among the embryos exhibited the $Z Z$ sex complement (Plate II a) and the females carried the $Z W$ complement (Plate II b). Three male embryos belonging to chicken female-pheasant male crosses had the cytogenetic make up of domestic chicken whereas two male embryos (table 2) had varying percentages of chicken and " hybrid " cells. Tetraploid cells were frequently noted in cultures of all hybrid embryos examined although the proportion of tetraploid cells in the two chimeric hybrids ( 18 out of 62 and I9 out of 66) was greater than in normal chicken embryo or " normal " hybrids (table 3 ).

The presence of exclusively chicken cells in some of the "hybrids " belonging to the chicken female-pheasant male crosses suggests either that the hens had stored some rooster sperms from previous matings in the " sperm nests " located in the infun- 
TABLE I

Gonadal Sex and Cytogenetic Sex of Chicken-Pheasant Hybrid Embryos

Sexes gonadique et cytogénétique des embryons hybrides poulet $\times$ faisan

\begin{tabular}{|c|c|c|c|c|c|c|c|}
\hline \multirow{2}{*}{ Crosses } & \multirow{2}{*}{ No. of Eggs } & \multicolumn{2}{|c|}{$\begin{array}{l}\text { Anatomic } \\
\text { Sex }\end{array}$} & \multicolumn{2}{|c|}{$\begin{array}{l}\text { Histologic } \\
\text { Sex }\end{array}$} & \multicolumn{2}{|c|}{$\begin{array}{l}\text { Cytogenetic } \\
\text { Sex }\end{array}$} \\
\hline & & $\begin{array}{l}\text { Paired } \\
\text { Gonad }\end{array}$ & $\begin{array}{l}\text { Single } \\
\text { Gonad }\end{array}$ & Testis & Ovary & $Z Z$ & WZ \\
\hline $\begin{array}{l}\mathrm{CH} \text { o } \mathrm{PH} \text { 우 } \\
\mathrm{CH} \text { क } \mathrm{PH} \text { 。 }\end{array}$ & $\begin{array}{l}19 \\
15\end{array}$ & $\begin{array}{l}12 \\
10\end{array}$ & $\begin{array}{l}7 \\
5\end{array}$ & $\begin{array}{r}16 \\
9\end{array}$ & $\begin{array}{l}3 \\
6\end{array}$ & $\begin{array}{r}16 \\
9\end{array}$ & $\begin{array}{l}3 \\
6\end{array}$ \\
\hline & 34 & 22 & 12 & 25 & 9 & 25 & 9 \\
\hline
\end{tabular}

TABLE 2

Chromosome Make up of Embryos Belonging to Chicken-Pheasant Crosses Composition chromosomique d'embryons provenant des croisements poulet $\times$ faisan

\begin{tabular}{|c|c|c|c|c|c|c|}
\hline \multirow{2}{*}{ Crosses } & \multirow{2}{*}{$\begin{array}{c}\text { No, of Embryos } \\
\text { Karyotyped }\end{array}$} & \multicolumn{2}{|c|}{ Sex } & \multicolumn{3}{|c|}{ Chromosome Make up } \\
\hline & & $\sigma$ & q & Hybrid & Chicken & Chimera* \\
\hline $\mathrm{CH}$ oै $\mathrm{PH}$ 우 & 19 & 16 & 3 & 19 & 一 & - \\
\hline $\mathrm{CH}$ 우 $\mathrm{PH}$ & 15 & 9 & 6 & 10 & $3^{*}$ & $2 *$ \\
\hline
\end{tabular}

* Embryos with ZZ sex complement.

TABLE 3

Distribution of Different Cell Types in Cultures of Chicken-Pheasant Hybrids

Distribution de différents types cellulaires dans les cultures d'hybrides poulet $\times$ faisan

\begin{tabular}{|c|c|c|c|c|c|c|c|}
\hline Crosses & Sex & $\begin{array}{l}\text { Type of } \\
\text { Embryo }\end{array}$ & $\begin{array}{l}\text { Diploid } \\
\text { Chicken } \\
\text { Cells }\end{array}$ & $\begin{array}{l}\text { Diploid } \\
\text { Hybrid } \\
\text { Cells }\end{array}$ & $\begin{array}{c}\text { Tetraploid } \\
\text { Chicken } \\
\text { Cells }\end{array}$ & $\begin{array}{l}\text { Tetraploid } \\
\text { Hybrid } \\
\text { Cells }\end{array}$ & Total \\
\hline $\mathrm{CH}$ ơ $\mathrm{PH}$ 우 & 우 & hybrid & 一 & 47 & - & 11 & 58 \\
\hline $\mathrm{CH}$ 우 $\mathrm{PH}$ & oै & chimera $n^{\circ} 1$ & 31 & 13 & 9 & 9 & 62 \\
\hline $\mathrm{CH}$ o $\mathrm{CH} \mathrm{o}^{\star}$ & ㅇ & chicken & 53 & 一 & 10 & $\rightarrow$ & 63 \\
\hline $\mathrm{CH} \sigma \mathrm{PH}$ q & t & hybrid & 一 & 37 & 一 & 14 & 51 \\
\hline $\mathrm{CH}$ 우 $\mathrm{PH}$ & $\hat{\sigma}$ & chimera $n^{\circ} 2$ & 22 & 25 & 17 & 2 & $6 n$ \\
\hline
\end{tabular}


dibulum (VAN DRIMMELEN, I95I) or that some of the hen's eggs are fertilized parthenogenetically. The fact that two of the hens used for hybridization were previously mated with domestic chicken roosters supports the possibility of fertilization of some of the eggs by rooster spermatozoa which have retained their viability in the hens reproductive tract. It has been shown previously that the spermatozoa stored in the infundibular sperm nests could be released into the lumen of the oviduct by experimentally distending the oviduct (GRIGG, I957). It is possible that the stimulus provided by the process of insemination with pheasant semen causes the release of the stored rooster sperms for fertilization. Alternatively, it is equally possible that the chromosomally confirmed chicken embryos of the chicken pheasant crosses are those resulting from parthenogenesis through polar body fusion. Parthenogenesis has been reported frequently in turkey (OLSEN, I960; PoOLE, I956) and may be also prevelant in chicken. Since the chicken embryos detected in this investigation are all males, the possibility of their origin through parthenogenesis cannot be ruled out.

The presence of chimeric embryos with hybrid cells and chicken cells are difficult to explain. One possibility is that the haploid chicken elements segregated at one of the early cleavage stages and that these haploid elements subsequently " doubled " to give the diploid chicken complement noted in approximately $33 \mathrm{p}$. I00 and $\mathrm{I} 8 \mathrm{p}$. Ioo of the cells in these embryos. It is also possible that the segregation of chicken chromosomes occured in one of the tetraploid "hybrid " cells during the course of embryonic development. Tetraploid cells have been noted frequently in some of the tissues of mammalian and avian hybrids (BASRUR, I969; OHNO, I968). Since the proportions of tetraploid hybrid cells noted in the chimeric embryos were similar to those detected in other hybrid and chicken embryos (table 3), it is unlikely that the original zygotes in these cases were of tetraploid constitution.

It is conceivable that the chimeric embryos are the result of double fertilization involving a pheasant and a chicken spermatozoa. If such an event had occurred in an ovum and its retained polar body, the failure of subsequent separation of these fertilized cells could give rise to an embryo which is composed of chicken and hybrid cells. The occurrence of these chimeric embryos may be interpreted as cytogenetic evidences of premature fertilization and/or impaired polar body separation in the females employed in the present crosses although the number of such embryos detected during this investigation is small. It is possible that in these instances, the polar body separation which coincides with ovulation in domestic chicken has been interrupted by the premature fertilization of the oocytes by a chicken and a pheasant spermatozoa.

Ręu pour publication en août 1972.

\section{ACKNOWLEDGEMENTS}

This investigation was supported in part by a grant from the National Research Council of Canada. Our sincere thanks are due to Professor B. S. Reinhart of the Department of Poultry and Animal Sciences, University of Guelph for his cooperation and to Mrs. Dorothy G. Friedman for the technical help. 


\section{RẾSUMÉ}

\section{LES CHROMOSOMES DE L'HYBRIDE FAISAN $\times$ POULE DOMESTIQUE}

L'analyse chromosomique de 34 embryons hybrides obtenus par les deux types de croisements entre des poulets domestiques (Gallus domesticus) Columbian Rock et des faisans (Phasianus colchicus) à collier a révélé que la majorité des embryons portaient une garniture haploïde de chacune des deux espèces. Trois embryons mâles d'un croisement faisan mâle par poule domestique étaient cytogénétiquement indiscernables de coqs domestiques, alors que deux autres embryons, obtenus par un croisement semblable, étaient des chimères, ayant à la fois des cellules de poulet et de faisan. La présence de caryotypes de poulet chez des embryons hybrides peut être due soit à une parthénogenèse chez la poule, soit à une fertilisation par du sperme resté en vie dans le tractus génital depuis un précédent accouplement avec un coq. On pense que les hybrides chimères quant à eux peuvent résulter d'une double fertilisation de l'ovule et de son globule polaire, l'une avec la semence expérimentale, l'autre avec du sperme de coq survivant, d'un précédent accouplement.

\section{REFERENCES}

Asmondson V. S., Lorenz F. W., I957. Hybrids of ring-necked pheasants, turkeys, and domestic fowl. Poultry Sci., 36, I323-I334.

BASRUR P. K., I969. Hybrid Sterility. In BEnIRSchKe : Comparative Mammalian Cytogenetics Springer, New York.

Basrur P. K., Gilman J. P. W., I963. Behaviour of two cell strains derived from rat rhabdomyosarcomas. J. Nat. Cancer Inst. 30, I63-185.

Bhatnagar M. K., I968. Cytogenetic studies on some avian species. Ph. D. Thesis, University of Guelph.

BENIRSCHKE K., I967. Sterility and fertility of interspecific mammalian hybrids. In BENIRSCHKE : Comparative Aspects of Reproductive Failure. Springer, New York.

GRIGG G. W., I957. The structure of stored sperm in the hen and the nature of the release mechanism. Poultry Sci., 36, 450-45 r.

Van Drimmelen G. C., I95I. Artificial insemination of birds by the intraperitoneal route. Onderstepoort J. vet. Res. Suppl. 1.

Olsen M. W., r96o. Nine year summary of parthenogenesis in turkeys. Proc. Soc. Expor. Biol. 105, 279-28r.

OHNO S., r966. Cytologic and genetic evidence of somatic segregation in mammals, birds and fishes. In vitro, 2, 46.5I.

Poole H. K., 1959. The mitotic chromosomes of parthenogenetic and normal turkeys. J. Heredity, 50, I50-I 54 . 
Metaphase chromosomes and partial karyotypes of two of the birds used for hybridization :

a) a female pheasan

b) a male chicken.

In the karyotypes, the macrochromosomes of pheasant and chicken are arranged in pairs in decreasing order of length whereas the microchromosomes, except those which are extremely small and thus elude photographic reproduction, are shown just as they appeared in the metaphase plates. Among the autosomes of chicken the chromosome pairs I, 2, 4 and 8 are biarmed whereas in pheasants only one pair (chromosome pair $\mathrm{I}$ ) is biarmed. The $Z$ chromosomes, which are morphologically similar in pheasant and chicken, belong to the fourth place in pheasant karyotype and to the fifth place in chicken karyotype. The $\mathrm{W}$ chromosome which is represented by an acrocentric in female pheasants is represented by a small metacentric in female chicken.

$$
\text { Aceto orcein } \times 2600 \text {. }
$$

\section{PLANCHE I}

Chromosomes métaphasiques et caryotypes partiels de deux des oiseaux utilisés pour l'hybridation :

a) une poule-faisanne,

b) un coq domestique.

Dans les caryotypes, les macrochromosomes du faisan et du poulet sont arrangés par paires, en ordre de longueur décroissante alors que les microchromosomes, sauf les tout petits qui, ainsi, échappent à la reproduction photographique, sont présentés tels qu'ils apparaissent sur les plaques métaphasiques. Parmi les autosomes du poulet, les paires chromosomiques 1,2, 4 et 8 ont deux bras alors que chez le faisan seule une paire (la paire chromosomique $n^{\circ} 1$ ) est de ce type. Les chromosomes $Z$, morphologiquement semblables dans les 2 espèces, se placent au $4 \mathrm{e}$ rang dans le caryotype du faisan, au 5e dans le caryotype du poulet. Le chromosome $W$, représenté par un acrocentrique chez la poule-faisanne, l'est par un petit métacentrique chez la poule domestique. 

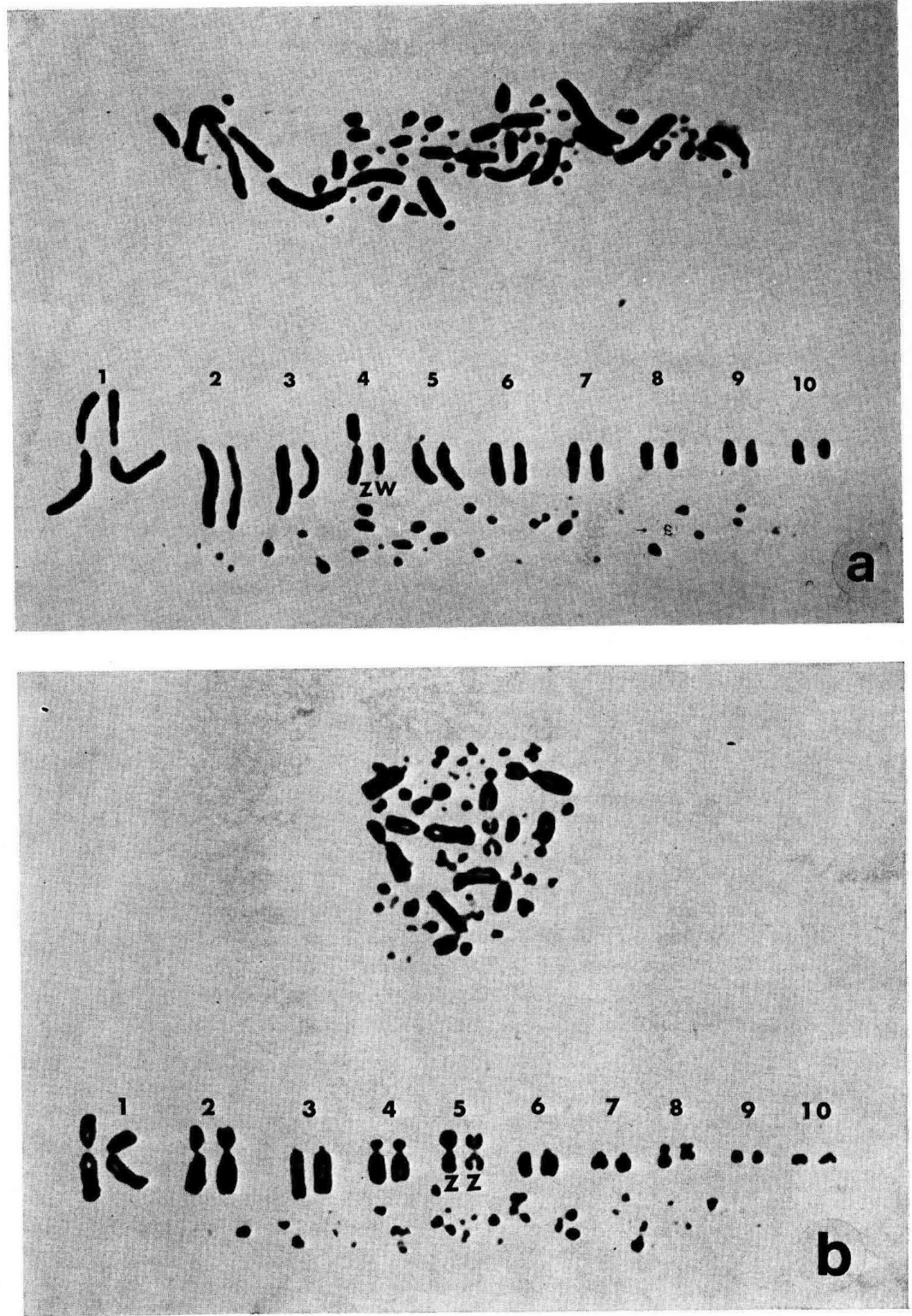

K. BASRUR, S. YAMASHIRO 


\section{PLATE II}

Metaphase plates and partial karyotypes of hybrids :

a) a male,

b) a female.

The male hybrid embryo was obtained from a chicken femalepheasant male cross and the female embryo was derived from a pheasant female-chicken male cross. With the exception of chromosome pair I and the sex complements shown in $b$ the arrangement of hydrid macro-chromosomes in pairs is entirely arbitrary.

Aceto-orcein. $\times 2600$.

\section{PLANCHE II}

Plaques métaphasiques et caryotypes partiels de l'hybride:

a) mâle

b) femelle

L'embryon hybride mâle provient d'un croisement poule domestique $\times$ coq faisan, l'embryon hybride femelle d'un croisement poule faisanne $\times$ coq domestique. A l'exception de la première paire et des compléments sexuels que l'on peut avoir en b l'arrangement des macrochromosomes hybrides est entièrement arbitraire.

Acéto-orcéine $\times 2600$ 


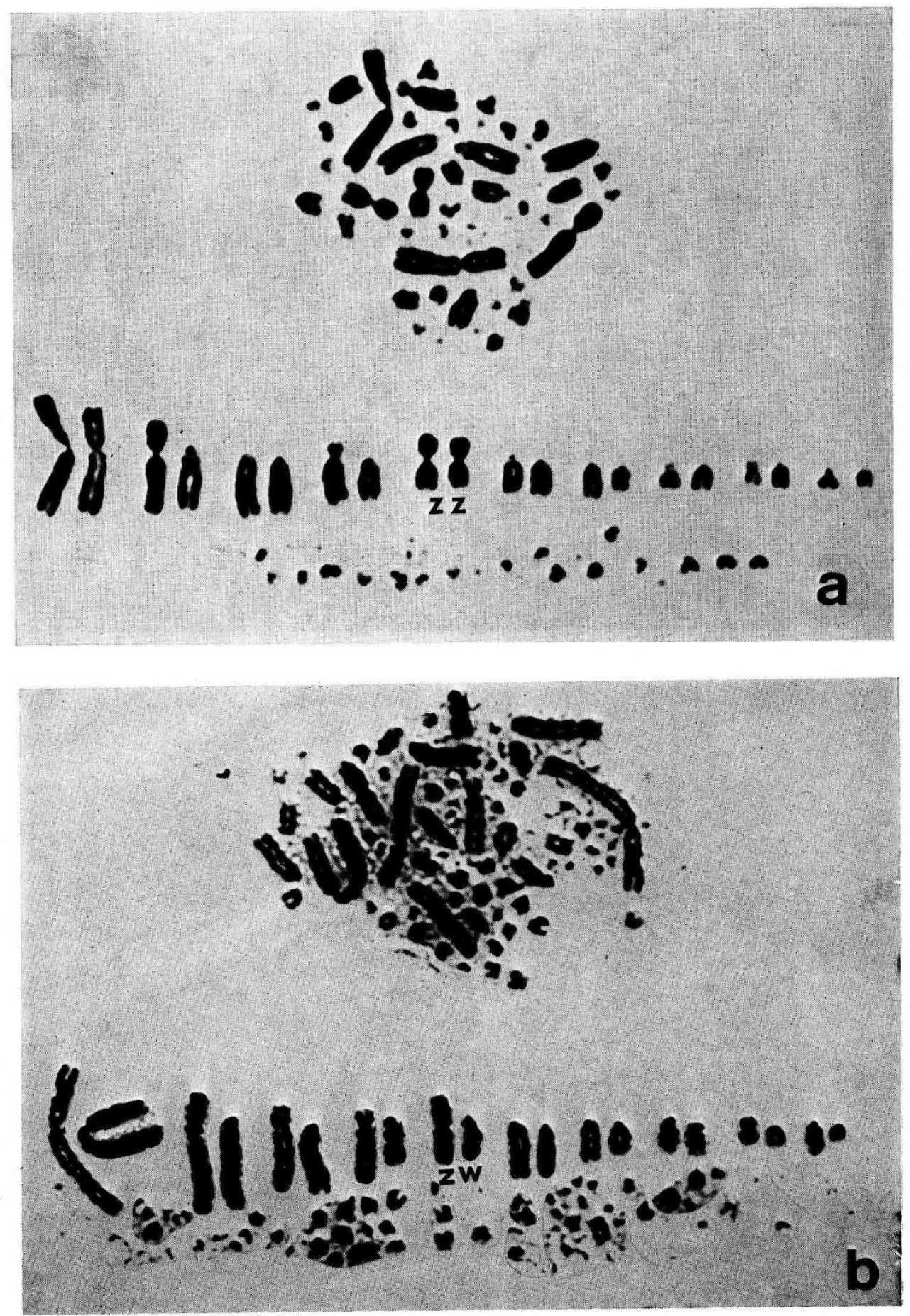

K. BASRUR, S. YAMASHIRO 